doubts lies not in less but more reliance on computers, in the form of the "convivial computing" of Papert's LOGO project. The aim of the project is to use computers as teachers, whose pupils will remain free of the hangups and fears of appearing foolish that human teachers frequently inspire. It is an impressive project, but surely not an answer to Dr Oatley's doubts. Yet what answer could he give? Perhaps there is none within his framework of physiological psychology and artificial intel-

\section{Protein turnover}

Protein Turnover in Mammalian Tissues and in the Whole Body. By J. C. Waterlow, P. J. Garlick and D. J. Millward. Pp. 804. (North-Holland: Amsterdam, New York and Oxford, 1978.) \$120; Dfl.276.

THIS is a scholarly book in the best sense of that term: Professor Waterlow and his colleagues know the subject matter thoroughly, think very clearly and write very well. It is an expensive volume, but the isotopically labelled materials you need to study protein metabolism in the whole animal are also expensive, and most workers in this difficult field could easily save the cost of the book by reading it carefully, and then designing their experiments more wisely.

A frontispiece to the book indicates a "scientific heritage" going back to the mid-eighteenth century, but the genealogy is not one of orderly succession. In the late 1930s Schoenheimer and his colleagues made an astonishing leap forward by showing that metabolic precursors of all kinds, and in particular amino acids, could be labelled with stable isotopes, and thus that their metabolism in whole animals and tissues could be followed. The technical problems which had to be overcome to carry out this work were so great that no other laboratory was able to carry on the torch, but as a result of Schoenheimer's work, biological scientists learned to regard the body less as a fixed machine which ran on dietary fuel, and more like a military regiment in which the structure is in dynamic equilibrium with the fuel-in this case, the recruits.

It has proved unexpectedly difficult to continue where Schoenheimer left off. In the past 20 years techniques for measuring both radioactive and stable isotopes have greatly improved. It is deceptively easy to carry out tracer studies with labelled amino acids, but all too often they are impossible to interpret. Good tracer studies need many skills, and if the investigator's grasp of biochemistry or mathematics is inadequate, mere technical accuracy is of no use. This book concentrates on the biochemistry and mathematics. ligence. This may explain his choice of a quotation from Doris Lessing at the beginning of the book: "And when a book's pattern and the shape of its inner life is as plain to the reader as it is to the author-then perhaps it is time to throw the book aside, as having had its day, and start again on something new."

A. W. Still is Lecturer in Psychology at the University of Durham, UK.

The first section (164 pages) is on processes: a review of protein synthesis, degradation, and amino acid pools and transport. The key sentence is: "No measurement of the rate of incorporation of a labelled amino acid into protein can be used to calculate the rate of protein synthesis unless the specific activity of the free amino acid at the site of protein synthesis is also known." The second section, on methods (263 pages) starts with a useful introduction to mathematical models. Non-mathematicians should read this, as the study of anything so complex as whole body protein turnover requires models, and the more you know about

\section{Seed \\ development}

Physiology and Biochemistry of Seeds in Relation to Germination. Vol. 1: Development, Germination, and Growth. By J. D. Bewley and M. Black. Pp. 306. (Springer: Heidelberg and Berlin, 1978.) DM90.

THE authors of this first volume of a twovolume work have concerned themselves with the physiology and biochemistry of seed development, germination and seedling growth. Approximately one-third of the book deals with seed structure and the development of the seed on the parent plant, and the remainder considers germination and seedling growth with particular attention to the mobilisation of reserves and the control of mobilisation. The interest in these topics and the use of seed and seedling material for much research in the plant sciences gives the subject of this volume a considerable importance for both teaching and research. Part of the work provides an excellent text for advanced students, one of its strongest points being its critical treatment of those dynamic aspects of seed development and germination, such as nucleic acid and protein synthesis and cereal aleurone layer studies, which have seen research work of a high quality in recent years. In areas in which there has been less distinguished recent work, such as the study of seed and seedling respiration and its control, the authors seem to their advantages and limitations the more likely you are to use them appropriately. The next chapters deal with methods for measuring protein turnover in the whole body by observing free amino acid labelling, in individual tissues by observing incorporation of label into tissue protein, and some special cases such as isolated perfused organs.

The remaining 323 pages of text on results draws heavily on the work done by Professor Waterlow and his colleagues, and this concludes with a most stimulating chapter on directions of future research. There are great technical and intellectual challenges for the next generation of research workers, in a field ready for a new explosion of knowledge. The problem is that the body is much less homogeneous than a military regiment, or even an army, as there are many more types of protein, with different kinetics, than there are types of soldier. For those who take up the challenge to discover how and why protein is turned over in tissues and animals (including man) this book is an excellent guide.

J. S. Garrow

J. S. Garrow is at the Clinical Research Centre, Harrow, UK.

have been rather less critical and somewhat over-generous in their assessment of the literature.

The authors' aim for comprehensiveness has resulted in the book having some rather dull sections, for example, on structure and on the chemistry and biochemistry of reserve materials, so that parts of the book have the character of a reference work, a feature of which is in keeping with the rather high price of the volume. Of course such a slim volume cannot really provide a comprehensive coverage of the subject and therefore each chapter is followed by some more general references so that the reader can fill out the topic. One vital and rather difficult topic has received very inadequate attention: the question of the measurement of germination, which receives less than two pages and exhortations to read the literature. Something more authoritative was called for here.

There are few errors in this attractively produced book. Most of the Tables and Figures have originated fairly directly from the literature and I found most value in those that had been specifically produced by the authors. In volume two I hope that the authors will give more scope to their illustrative talents and I look forward to the early appearance of this volume and to its treatment of the real problem, that of seed dormancy.

J. W. Bradbeer

J.W. Bradbeer is Professor of Botany at King's College, University of London, UK. 